\title{
Characteristics of Incident Testicular Cancer in Lebanon - 1990-2015 Single Institutional Experience
}

\author{
Tarek Assi*, Fadi Nasr, Elie El Rassy, Toni Ibrahim, Hicham Jabbour, Georges \\ Chahine
}

\begin{abstract}
Background: Despite the fact that testicular cancer is a major health issue with its increasing incidence, very few studies have described its characteristics in the Middle East, particularly in Lebanon. Materials and Methods: We report in this paper a retrospective pilot study of the characteristics of testicular cancer in Lebanon. The demographic, epidemiologic and survival characteristics of 178 patients diagnosed between 1990 and 2015 at an oncology clinic affiliated to Hotel Dieu de France Hospital were analyzed. Results: The mean age at diagnosis was $32 \pm 10$ years. The most prevalent testicular tumor was the germ cell type (GCT) (95.2\%) of which non-seminomatous tumors (NST) were the commonest $(64.7 \%)$. Most of our patients were diagnosed at an early stage. Lymph node spread affected most commonly the retroperitoneal region and distant visceral metastases occurred in $14.6 \%$. All patients underwent orchiectomy with $67 \%$ receiving adjuvant treatment, mainly chemotherapy. After a median follow up of 2,248 days $(75.9$ months) 16 patients were reported dead. Two, five and ten-year overall survival rates were $96 \%, 94 \%$ and $89 \%$ respectively. The median overall survival rate was not reached. Conclusions: Despite being part of the developing world, demographic, epidemiologic and survival analyses of testicular cancer reported in our study are in line with those reported from developed countries and would allow us to extrapolate management plans from these populations.
\end{abstract}

Keywords: Epidemiology - survival - testicular cancer - Lebanon - Middle East

Asian Pac J Cancer Prev, 17 (4), 1899-1902

\section{Introduction}

Testicular cancer is a rare tumor accounting for $1 \%$ of cancers in men with an actual increasing prevalence worldwide estimated to 5.6 per 100,000 men per year. Epidemiologic data concerning testicular tumors vary between countries, ethnicities and age groups (Seer Cancer Statistics Factsheets: Tesis Cancer. 2001).

Effectively, Northern European countries had an age adjusted rate of 12.2 per 100,000 men in contrast to $<0.7$ per 100,000 in Asian and African countries (Chia et al., 2010; Trabert et al., 2015). Lebanon is a Middle Eastern country located on the Eastern shores of the Mediterranean Sea and is characterized by large gamily sizes and rapid population growth (Barbour and Salameh, 2009). Unfortunately, the National Cancer Registry has been inactive and epidemiologic data are sparse and limited to small sample size (Chahine et al., 2015). Recent reports of the pathologic characteristics of testicular cancer showed similar distributions to developed countries, however, survival analysis of any Middle Eastern population is missing (Assi et al., 2015). The present study analyzed the epidemiologic and demographic characteristics of testicular tumors and assesses our 25-year experience in managing this tumor.

\section{Materials and Methods}

\section{Study design and setting}

The study population results from the archived records of an oncology clinic affiliated to Hotel Dieu de France University Hospital, a tertiary and referral center serving Beirut, considered a highly qualified center in oncologic disorders. This study includes all patients with a confirmed diagnosis of testicular tumor (ICD-O-3 C62) diagnosed between 1990 and 2015(Fritz et al., 2000). Records with missing data excluded the corresponding patient from this study.

\section{Participants}

After pathologic confirmation and adequate staging, our patients received a primary chemotherapy of blemocyine, etoposide and cisplatin (BEP). Response to treatment is assessed at one month after completion of the chemotherapy regimen with contrast-enhanced abdomino-pelvic computed tomography (CT) scan and tumor markers including serum alfa-fetoprotein (AFP), 
serum beta-human chorionic gonadotrophin ( $\beta$-HCG), and serum lactase dehydrogenase (LDH). Follow up included routine tumor markers and abdomino-pelvic CT scans at three month intervals for the first two years. Later, patients were followed up biannually with abdomino-pelvic CT scan once yearly.

\section{Data source and variables}

Epidemiologic data and information concerning the histologic type, location, stage at diagnosis were obtained from the pathology records. The mode of presentation, treatment regimen, and progression free survival were retrieved from the clinic records. Age was classified into subgroups of 15 years according to the National Center Data Base and participants were grouped by age with 34 years as a cut-off point being the average age in corresponding series. All tumors are staged according to American Joint Committee Cancer (AJCC) (Fleming et al., 1997).

\section{Statistical methods}

SPSS v20.0 software was used for statistical analysis. Our clinical data is expressed in mean \pm standard deviation (SD), or median, or percentage. The relationships between each of the variables are assessed by Pearson's

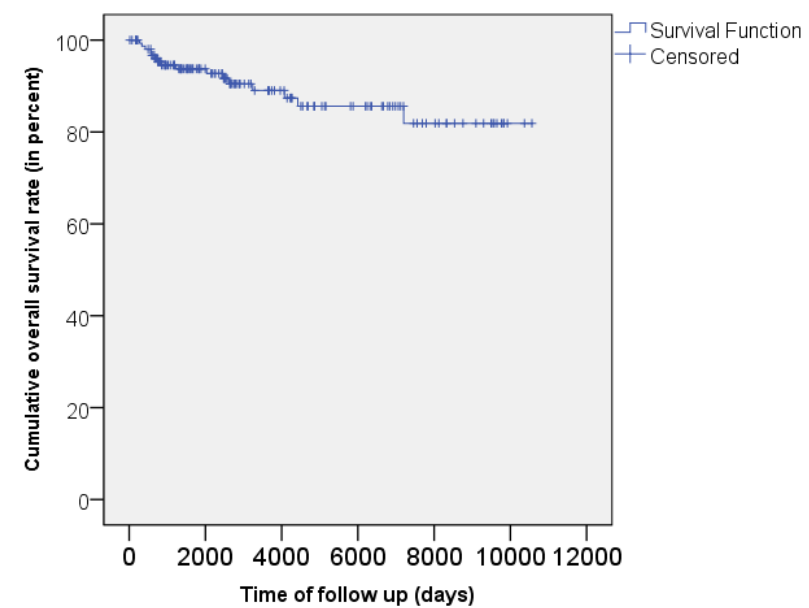

Figure 1. Kaplan-Meier Overall Survival Curve for Testicular Cancer Patients

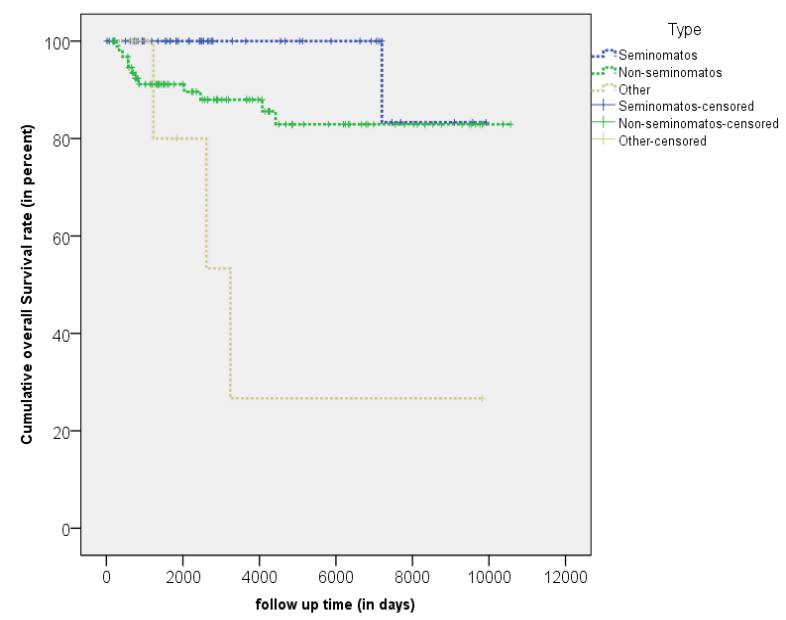

Figure 2. Kaplan-Meier Overall Survival Curves for Testicular Cancer Patients According to Tumor Type correlation. Time-to-event end points were summarized by using Kaplan and Meier estimates. A p value $<0.05$ was considered significant.

\section{Results}

\section{Patient characteristics}

A total of 178 patients diagnosed with testicular cancer were included in this study with a median age at diagnosis of $32 \pm 10$ years (range 15-72 years). The group had an average height of $176 \mathrm{~cm}$ and an average weight of $72 \mathrm{~kg}$. Testicular lump or edema was the most common revealing sign of testicular cancer ( $89.3 \%$ of patients) followed by testicular pain $(16.9 \%)$. Cryptorchidism was reported in 7 patients $(3.9 \%)$.

\section{Tumor characteristics}

According to our data, the most prevalent testicular tumor is the germ cell type (GCT) $(95.2 \%)$ of which non-seminomatous tumors (NST) were the commonest (64.7\%). Among the NST, $59.3 \%$ of the patients were diagnosed with mixed GCT and $20.3 \%$ with embryonal carcinoma. In the non-GCT which was found in only 8 patients $(4.8 \%)$, three patients had Leydig cell carcinoma, two had testicular lymphoma while sarcoma, Sertoli Cell carcinoma and Sex cord stromal tumor were each diagnosed at only one occasion. With further stratification of the mixed GCTs, embryonal carcinoma was the most found component in association with other subtypes $(82.2 \%)$; the most common combination of embryonal carcinoma was found with teratoma, yolk sac tumor and seminoma in $30 \%, 25.8 \%$, and $20 \%$ respectively.

The right testicle was more frequently affected than its left counterpart $(52.2 \%)$. The average size of the testicular tumor at diagnosis was $4 \pm 3 \mathrm{~cm}$ (range 0.8-1 $\mathrm{cm}$ ). The mean levels of tumor markers were as follows, AFP, $1137 \mathrm{ng} / \mathrm{ml}$ (range <1 and 133700), $\beta$-HCG, 4008 $\mathrm{mUI} / \mathrm{ml}$ (range $<1$ and $270000 \mathrm{mIU} / \mathrm{ml}$ ), and $\mathrm{LDH}, 208$ $\mathrm{U} / \mathrm{L}$ (range $<1$ and 2636). Almost half of our patients were diagnosed at an early stage (48\%) followed by $36 \%$ and $16 \%$ for the locally advanced stage and metastatic disease respectively. Lymph node spread occurred in 74 patients

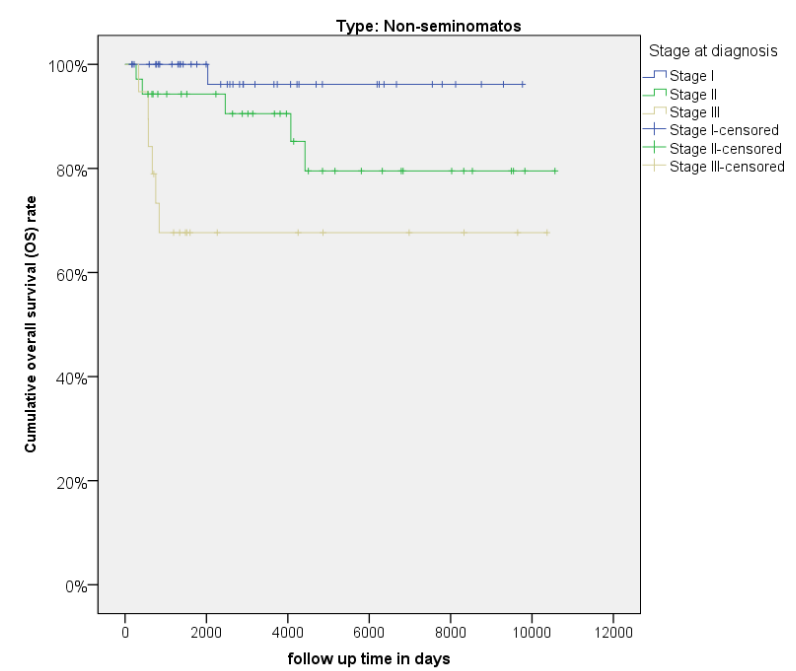

Figure 3. Kaplan-Meier Overall Survival Curve for Testicular Cancer Patients According to Tumor Stage 
Table 1. Comparison of Survival Analyses between Different Continents and Countries

\begin{tabular}{|c|c|c|c|c|c|c|c|c|}
\hline Continent & Country & Study & $\begin{array}{l}\text { Study } \\
\text { Period }\end{array}$ & $\begin{array}{l}\text { Number } \\
\text { of Patients }\end{array}$ & $\begin{array}{c}\text { Age } \\
\text { (Years) }\end{array}$ & Subtypes & $\begin{array}{c}\text { Staging } \\
\text { Distribution }\end{array}$ & $\begin{array}{c}\text { Overall } \\
\text { Survival }\end{array}$ \\
\hline \multirow{3}{*}{ Asia } & Lebanon & $\begin{array}{c}\text { Assi et al } \\
2015 \text { (our } \\
\text { series) }\end{array}$ & $1990-2015$ & 179 & $\begin{array}{c}32 \\
(\text { Mean })\end{array}$ & $\begin{array}{c}\text { Seminona: } 33.7 \% \\
\text { NST:61.8\% Non- } \\
\text { GCT: } 4.5 \%\end{array}$ & $\begin{array}{c}\text { Stage 1: } 48.0 \% \\
\text { Stage 2: } 36.0 \% \\
\text { Stage 3: } 16.0 \% \\
\text { Localized: }\end{array}$ & $\begin{array}{l}\text { Two-year: } 96 \% \\
\text { Five-year: } 94 \% \\
\text { Ten-year: } 89 \%\end{array}$ \\
\hline & Japan & $\begin{array}{c}\text { Oshima et } \\
\text { al } 2001\end{array}$ & $1975-1992$ & 709 & NA & $\begin{array}{c}\text { Seminona: } 28.3 \% \\
\text { NST:66.7\% Non- } \\
\text { GCT: } 5.3 \%\end{array}$ & $\begin{array}{c}61.2 \% \\
\text { Regional: } \\
13.8 \% \\
\text { Distant: } 25 \%\end{array}$ & $\begin{array}{c}\text { Five-year: } \\
75.2 \%\end{array}$ \\
\hline & Pakistan & $\begin{array}{c}\text { Bhatti et al } \\
2014\end{array}$ & $2009-2012$ & 247 & $\begin{array}{c}33 \\
\text { (Median) }\end{array}$ & $\begin{array}{c}\text { Seminona: } 59.4 \% \\
\text { NST: } 37.4 \% \text { Non- } \\
\text { GCT: } 3.2 \%\end{array}$ & $\begin{array}{l}\text { Stage 1: } 37.2 \% \\
\text { Stage 2: } 12.6 \% \\
\text { Stage 3: } 50.2 \%\end{array}$ & $\begin{array}{c}\text { Five-year: } \\
96 \%(\mathrm{Sem}) \\
\text { Five-year: } 90 \% \\
\text { (NST) }\end{array}$ \\
\hline \multirow{4}{*}{ Europe } & Lithuania & $\begin{array}{c}\text { Juska et al } \\
2011\end{array}$ & $1999-2002$ & 183 & NA & $\begin{array}{c}\text { Seminona: } 45.3 \% \\
\text { NST: } 48.9 \%\end{array}$ & $\begin{array}{l}\text { Stage 1: } 37.2 \% \\
\text { Stage } 2: 26.8 \% \\
\text { Stage } 3: 25.1 \% \\
\text { Stage } 4: 6.01 \%\end{array}$ & $\begin{array}{c}\text { One-year: } 83 \% \\
\text { Five-year: } \\
71.2 \%\end{array}$ \\
\hline & Germany & $\begin{array}{l}\text { Stang et al } \\
2013\end{array}$ & $1997-2006$ & 11,508 & $\begin{array}{c}36(\mathrm{Me}- \\
\text { dian })\end{array}$ & $\begin{array}{l}\text { Seminona: } 62.3 \\
\% \text { NST: } 34.2 \% \\
\text { Non-GCT: } 3.5 \%\end{array}$ & NA & $\begin{array}{c}\text { Five-year: } \\
96.7 \%\end{array}$ \\
\hline & Slovakia & $\begin{array}{l}\text { Ondrusova } \\
\text { et al } 2009\end{array}$ & $1993-2002$ & 1805 & $\begin{array}{c}34 \\
\text { (Mean) }\end{array}$ & $\begin{array}{c}\text { Seminona: } 38.4 \% \\
\text { NST: } 57.4 \% \\
\text { Non-GCT: } 4.2 \%\end{array}$ & NA & $\begin{array}{l}\text { Five-year: } \\
96.2 \%\end{array}$ \\
\hline & Turkey & $\begin{array}{l}\text { Ozgun et al } \\
2013\end{array}$ & $2008-2013$ & 96 & $\begin{array}{c}26.4 \\
(\text { Mean })\end{array}$ & $\begin{array}{c}\text { Seminona: } 17.7 \% \\
\text { NST: } 82.3 \%\end{array}$ & $\begin{array}{l}\text { Stage 1: } 46.9 \% \\
\text { Stage 2: } 30.2 \% \\
\text { Stage 3: } 22.9 \%\end{array}$ & $\begin{array}{l}\text { Five-year: } \\
90.2 \%\end{array}$ \\
\hline Africa & Tanzania & $\begin{array}{c}\text { Chalya et al } \\
2014\end{array}$ & 2004-2014 & 56 & $\begin{array}{l}28(\mathrm{Me}- \\
\text { dian })\end{array}$ & $\begin{array}{l}\text { Seminona: } 50.1 \% \\
\text { NST: } 32 \% \text { Non- } \\
\text { GCT: } 17.9 \%\end{array}$ & $\begin{array}{c}\text { Stage 1: } 3.6 \% \\
\text { Stage 2: } 10.6 \% \\
\text { Stage } 3: 25 \% \\
\text { Stage } 4: 39.3 \%\end{array}$ & $\begin{array}{l}\text { Five-year: } \\
22 \% *\end{array}$ \\
\hline America & USA & $\begin{array}{l}\text { Stang et al } \\
2013\end{array}$ & $1997-2006$ & 10774 & NA & $\begin{array}{c}\text { Seminona: } 58 \% \\
\text { NST: } 39.9 \% \text { Non- } \\
\text { GCT: } 2.1 \%\end{array}$ & NA & $\begin{array}{c}\text { Five-year: } \\
96.3 \%\end{array}$ \\
\hline
\end{tabular}

*Only 18 patient's data were accessible; GCT, germ cell tumors; NA, not available; NST, non-seminomatous tumors; OS, overall survival; Sem, seminoma; St, stage; yr, year 39, 303-6

(41.6\%) and affected most commonly the retroperitoneal region $(39.3 \%)$. Distant metastases were detected in 26 patients $(14.6 \%)$ with the lungs being the primary site of distant spread (88.5\%) followed by the liver (30.7\%) and only one patient presented with brain metastases.

\section{Treatment and management}

All patients underwent unilateral orchiectomy with 111 patients $(67.3 \%)$ receiving adjuvant chemotherapy. Among the latter, chemotherapy was the most common adjuvant therapy in more than $97 \%$ of the patients. BEP protocol was the most common chemotherapeutic protocol administered (64.9\%) followed by EP protocol (Etoposide and Cisplatin) (20.9\%) and single agent Carboplatin $(9.9 \%)$. Adjuvant radiotherapy was only given to 3 patients $(2.7 \%)$. Subsequently to adjuvant therapy, 34 patients relapsed (19.1\%) after an average time of 32.9 months (range 1.9 and 215.9 months). The most common chemotherapeutic protocol given in the second line setting was VIP (Etoposide, Ifosfamide and Cisplatin) (41.6\%) followed by VeIP (Vinblastine, Ifosfamide and Cisplatin) (17.6\%).

\section{Survival analysis}

Figure 1 illustrates the survival analysis of testicular cancer patients after a median follow up of 2248 days (75.9 months) with 16 patients reported dead. Two, five and ten-year overall survival (OS) rates were $96 \%, 94 \%$, and $89 \%$ respectively. Median OS rate was not reached. Mean OS for all testicular cancer patients was 9230 days (307.7 months). Pathologic subgroup survival analyses showed that patients diagnosed with seminomas survived longer that those with NST ( 9468 vs 9097 days; $p=0.041$ ). Subgroup analyses by tumor type showed a median OS for non-GCT of 3240 days (108 months) and it was not reached in both the seminomatous and NST subgroups (Figure 2). Furthermore, analyses by stage of the tumor showed a significant difference in survival between the three different stages: Stage 1 (9468 days), Stage 2 (8981 days) and Stage 3 (7220 days) $(\mathrm{p}=0.005)$ (Figure 3$)$.

\section{Discussion}

Although various worldwide reports highlighted the increased incidence of testicular cancer, the epidemiologic characteristics of this tumor in the Middle East and Eastern Mediterranean region are not elucidated. Nevertheless, the efficacy of the adopted treatment regimens and their impact on survival are not assessed(Nigam et al., 2015). Effectively, data concerning the survival of patients with 


\section{Tarek Assi et al}

testicular cancer in undermined regions are lacking except for very limited published papers reporting low survival rates (Chalya et al., 2014). To our knowledge, this is the first study to report the survival rates among testicular cancer patients in the Middle Eastern region.

Demographic and epidemiological characteristics of patients with testicular cancer are comparable to those reported from developed countries (Table 1). Lebanese patients are diagnosed at 32 years of age, most commonly at an early stage with testicular lump being the most common presenting complaint followed by unspecific sensation of pain or heaviness similar to the published data (Garner et al., 2005). We attribute the increased percentage of early diagnosis to the high level of awareness and anxiety that affect young Lebanese patients upon detection of a testicular lump or pain (Saab et al., 2014).Similarly to our experience, cryptorchidism is the most established risk factor for testicular cancer occurring in 5-10\% of patients (Ferguson and Agoulnik, 2013; Lip et al., 2013, p. 2013). Pathologic stratification of the testicular tumors showed that NST were almost twice more prevalent than the seminomatous subtype and that almost two-thirds of the NST were mixed germ cell tumors. These epidemiological data vary widely between countries and populations with large discrepancy in the sociological and environmental patterns guiding each region (Assi et al., 2015).

Initial management of testicular tumors relies on orchiectomy followed by subsequent active surveillance or adjuvant treatment.In comparison to the five year experience of 13 country registries where only one third of the patients received chemotherapy and radiotherapy, two thirds of our patients received adjuvant standard chemotherapy and only 3 patients received radiotherapy (Sant et al., 2007). Recent data from the Spanish experience of more than 500 patients reports an increased exposure to chemotherapy but is still limited to almost $50 \%$ (Moreno et al., 2015). Interestingly, our study reports an increased OS (2- and 5-year OS of $98 \%$ and $94 \%$ respectively) despite the limited resources of the Lebanese society. Our survival rates are comparable to other developed countries and surpass those of less developed regions in Africa and Central Europe (Table 1). These encouraging results could be attributed to the early detection of testicular cancer, the successful treatment and surveillance strategies. One possible bias is the increased prevalence of the seminoma subtype known for its better prognosis.

Despite the limitations by the small sample size, our study represents the first real-life experience of a highly curable tumor in a developing country with very limited resources. Demographic, epidemiologic and survival analyses of testicular cancer reported in our study are in line with those reported from developed countries and would allow us to extrapolate management plans from these populations.

\section{References}

Assi T., Rassy M, Nassereddine H, et al (2015). Distribution of testicular tumors in Lebanon: a single institution overview. Asian Pac. J. Cancer Prev, 16, 3443-6.

Barbour, B., Salameh, P. (2009). Consanguinity in Lebanon: prevalence, distribution and determinants. J Biosoc Sci, 41, 505-17.

Chahine G, El Rassy E, Khazzaka, et al (2015). Characteristics of incident female breast cancer in Lebanon, 1990-2013: Descriptive study of 612 cases from a hospital tumor registry. Cancer Epidemiol, 39, 303-6.

Chalya PL, Simbila S, Rambau PF, et al (2014). Ten-year experience with testicular cancer at a tertiary care hospital in a resource-limited setting: a single centre experience in Tanzania. World J Surg Oncol, 12, 1-8.

Chia VM, Quraishi SM, Devesa SS, (2010). International trends in the incidence of testicular cancer, 1973-2002. Cancer Epidemiol Biomark Prev, 19, 1151-9.

Ferguson L, Agoulnik AI, (2013). Testicular cancer and cryptorchidism. Front Endocrinol, 4, 32.

Fleming ID, Cooper JS, Henson DE, et al (1997). AJCC cancer staging manual. 5th ed. Philadelphia: Lippincott-Raven.

Fritz A, Percy C, Jack A, et al (2000). International classification of diseases foroncology. $3^{\text {rd }}$ ed Geneva: World Health Organization.

Garner MJ, Turner MC, Ghadirian P, et al (2005). Epidemiology of testicular cancer: An overview. Int J Cancer, 116, 331-9.

Lip SZL, Murchison LED, Cullis PS, et al (2013). A metaanalysis of the risk of boys with isolated cryptorchidism developing testicular cancer in later life. Arch Dis Child, 98, 20-26.

Moreno, A., Domínguez, A., Alpuente, C., et al (2015). Clinical presentation features of testicular cancer in public hospitals in the Autonomous Community of Madrid, Spain. Actas Urol Esp Engl, 39, 2-7.

Nigam, M., Aschebrook-Kilfoy, B., Shikanov, S., et al (2015). Increasing incidence of testicular cancer in the United States and Europe between 1992 and 2009. World J Urol. 33, 623-31.

Power DA, Brown RS, Brock, et al (2001). Trends in testicular carcinoma in England and Wales, 1971-99. BJU Int, 87, $361-5$.

Saab M, Noureddine S, Abu-Saad Huijer H, et al (2014). Surviving testicular cancer: the Lebanese lived experience. Nurs Res, 63, 203-10.

Sant M, Aareleid T, Artioli ME, et al (2007). Ten-year survival and risk of relapse for testicular cancer: A EUROCARE high resolution study. Eur. J. Cancer, 43, 585-592.

SEER Cancer Statistics Factsheets: Testis Cancer. National Cancer Institute. Bethesda, MD, http://seer.cancer.gov/ statfacts/html/testis.html, n.d.

Trabert B, Chen J, Devesa SS, et al (2015). International patterns and trends in testicular cancer incidence, overall and by histologic subtype, 1973-2007. Androl, 3, 4-12. 